\title{
Pandemics, economic freedom, and institutional trade-offs
}

\author{
Vincent Geloso' ${ }^{1} \cdot$ Kelly Hyde $^{2} \cdot$ Ilia Murtazashvili ${ }^{2}$
}

Accepted: 24 June 2021 / Published online: 19 July 2021

(c) The Author(s), under exclusive licence to Springer Science+Business Media, LLC, part of Springer Nature 2021

\begin{abstract}
We argue that institutions are bundles that involve trade-offs in the government's ability to provide public goods that affect public health. We hypothesize that the institutions underlying economic freedom affect the mix of diseases by reducing diseases of poverty relative to diseases of commerce (those associated with free movement of people, such as smallpox or COVID-19). We focus on smallpox and typhoid fever in the late nineteenth century and early twentieth century in order to build on recent work that make arguments similar to ours, especially the framework Werner Troesken sets forth in The Pox of Liberty. Our evidence shows that economic freedom, in multiple periods of time and settings prior to the eradication of smallpox in the second half of the twentieth century, reduced typhoid mortality but had no effect on smallpox deaths. The implication for COVID-19 is that the trade-off between fighting the pandemic and preserving economic freedom may not be too severe in the short run. However, in the long run, the wealth benefits from economic freedom are likely to be crucial in reducing vulnerability to diseases of commerce primarily from their impact on comorbidities (such as diabetes and heart disease). Thus, economic freedom is on balance good for public health, which suggests that it, while requiring trade-offs, might be the best institutional bundle for dealing with pandemics.
\end{abstract}

Keywords Pandemic · COVID-19 · Economic history · Institutions · Disease · Economic freedom

JEL Classification H41 · H51 · I31 · N30

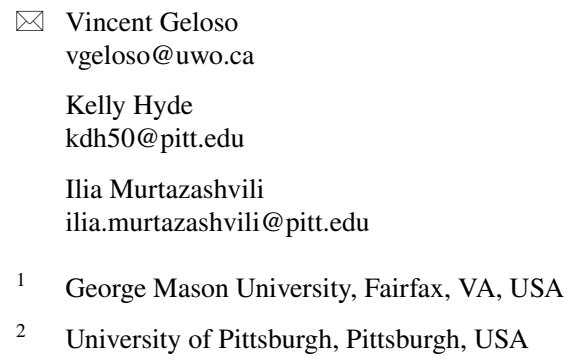




\section{Introduction}

The spread of COVID-19 initiated important debates among economists about the proper role of government in dealing with pandemics. That discussion occurred within the general framework of market failure theory. More specifically, markets alone will not provide the socially optimal level of mitigation and prevention. Thus, coercive measures, including economic lockdowns, were justified.

The economic justification for lockdowns follows from the majority view in the fields of both public economics and economic history, in which public health measures (such as swamp drainage to combat malaria, water sanitation to curb typhoid fever) are deemed to be a public good. ${ }^{1}$ For example, water-supply improvements in the form of filtered water and sewers contributed to massive improvements in public health as measured by typhoid deaths in American cities between 1850 and 1920; they greatly reduced waterborne pathogens, such as yellow fever (transmitted by mosquitos, a problem exacerbated by lack of sewers) and typhoid fever (spread through unsanitary water) (Meeker, 1972). Along these lines, Bleakley (2007) argues that an environment free of disease is a public good and that what is needed is to more precisely measure the long-run benefits from improved public health against the short-run costs of providing the public good.

In the present paper, we contest the majority view. While we do accept that certain diseases, such as COVID-19 and smallpox, have features that make public health measures public goods, the majority view glosses over important institutional trade-offs. Whereas the majority view accepts that choices can be made between individual institutions, we argue that institutions are bundles. Choosing bundle A, composed of public goods $\mathrm{B}$ and $\mathrm{C}$, necessitates the rejection of bundle $\mathrm{X}$, composed of public goods $\mathrm{Y}$ and $\mathrm{Z}$, even though the best bundle (which would comprise $\mathrm{B}$ and $\mathrm{Z}$ ) would provide the most utility. In other words, there is a constraint on institutional choice whereby we must take institutions as package deals.

This approach to conceptualizing institutional choice is particularly important in the practical case of dealing with disease environments. Infectious diseases that could spawn pandemics, such as COVID-19 and smallpox, can be dealt with quite effectively with the use of both weak and strong coercive tools: quarantines, curfews, mandatory tests, mandatory vaccination, mandatory disclosure of health status, mandatory acquisitions of certain items, and so on (Goodman-Bacon \& Marcus, 2020).

However, tools such as these necessitate investments on the part of states that are, to some degree, mutually exclusive with institutional features such as economic freedom, including strong property rights protections and judicial protections of individual rights. ${ }^{2}$ As Leeson and Thompson (2021) point out, many public health

\footnotetext{
1 See Buchanan (1968) for a theoretical presentation and Easterlin (1999) and Kitchens (2013) for an example from economic history.

${ }^{2}$ Readers should notice that we are not referring to the size of government, which is a component of economic freedom indexes. This is to reflect the literature that points to the ability of high levels of economic freedom (in the other components of the indexes) to be sustained in the presence of high levels of government spending (see more below).
} 
interventions involve the ability of governments to reallocate important quantities of resources towards (or away from) certain ends. The ability to perform this reallocation requires a strong state which is why Geloso and Salter (2020) point out that there are several examples of authoritarian regimes ${ }^{3}$ that are able expend considerable efforts-in comparison with market-oriented liberal democracies-by disregarding political rights and economic freedoms. Murray et al. (2013) point to similar evidence when they show that countries with high levels of pathogens prevalence tends to be associated with more authoritarian regimes. To the extent that economic liberties are tied to economic development, a trade-off must be made. Countries with potent states may be better able to deal with infectious diseases but less able to foster economic growth (Geloso \& Murtazashvili forthcoming; Coyne \& Yatsyshina 2021).

Some economists have noticed such a trade-off in the case of the COVID-19 pandemic. For example, McCannon and Hall (2021) showed that state-level stayat-home orders were issued earlier in economically unfree states. Similarly, Geloso and Murtazashvili (2021) show that the higher values of stringency index of policy responses to COVID-19 developed by OurWorldInData.Org ${ }^{4}$ was significantly associated, after controlling for confounding factors, with lower values of democratization and economic freedom. Thus, institutional bundles that permit strong public health measures do show associations with lower levels of economic freedom.

This trade-off in terms of institutional bundles also implies a trade-off in terms of health outcomes that are theoretically ambiguous. The ability to deploy heavyhanded public health measures may reduce deaths from certain types of diseases (e.g. epidemic-related deaths) on the one hand. On the other hand, the institutional trade-off (i.e. fewer economic freedoms) may cause slower economic growth-something that the literature on economic freedom and growth suggests (Hall \& Lawson, 2014). As economic development similarly reduces deaths from other types of causes (e.g. malnutrition and water-borne diseases), the slower rate of growth has adverse health consequences. As a result, the government institutions that deal with epidemics may end up increasing mortality from other sources. In other words, the types of institutions could affect the mix of mortality causes. The net effect on levels of mortality, however, is ambiguous. ${ }^{5}$

\footnotetext{
3 They point to the examples of the former Communist bloc countries as well as Cuba and Ethiopia which achieved high-level health outcomes given their per capita income levels. It should also be noticed that Geloso et al. (2020) do not argue that health outcomes are better under dictatorships, merely that such regimes have more ability to forcibly reallocate resources to health services.

4 The index is a composite measure of workplace closures, cancellation of public events, restrictions on public gatherings, closures of public transport; stay-at-home requirements; public information campaigns; restrictions on internal movements; and international travel controls.

5 Further complexifying the nature of the trade-off is that economic freedom is associated with the ability to make consumption choices that may be detrimental to health outcomes. For example, the literature on obesity - and the mortality risks associated with it - points to a positive association between obesity and income (Egger et al., 2012). Unsurprisingly, given the relationship between income and economic freedom, there is also a positive association between economic freedom and obesity rates (Lawson et al., 2016).
} 
The only scholar, to our knowledge, who has identified these complex trade-offs is the late economic historian Werner Troesken (2015). Applying his work to the case of smallpox mitigation in the late nineteenth and early twentieth centuries, Troesken points out that the United States was an exceptionally rich country for the same reasons that it was plagued with an exceptionally high level of mortality from smallpox. The constitutional restraints that protected property rights also limited the ability of state and local governments to push for public health measures to combat smallpox. Troesken then highlighted that the wealth that these restraints created also permitted important capital investments in water facilities that reduced mortality from waterborne diseases such as typhoid fever. Thus, the bundle of institutions that made the United States rich also required trading off more smallpox deaths for fewer typhoid deaths. However, while Troesken (2015: 99) made clear the outcome trade-off between income per capita and smallpox mortality, he left unanswered the question of whether lower levels of typhoid fever mortality decline overpowered the higher level of smallpox mortality. Moreover, Troesken relied only on analytical narratives to make his case and thus did not directly test the role of economic freedom on health outcomes. This was because there were no historical measures of economic freedom for the time period that interested him.

In this paper, we provide the first three steps to expand on Troesken's powerful insights. First, we formally test for the possibility of a different relationship between economic freedom and health outcomes. Second, we attempt to weight the net health effects of the trade-off institutional bundles between typhoid fever and smallpox. Third, we attempt to generalize his reasoning in order to provide a framework for future research on the political economy of public health that relies on his insights.

To do so, we make use of new data that measure economic freedom in the late nineteenth and twentieth centuries at both the international and subnational levels to make an econometric attempt at testing the trade-off that Troesken highlights. If Troesken is correct, economic freedom should have no statistically significant effect on smallpox mortality or it may even increase it, while it should have a significant negative effect on typhoid fever mortality.

We present different sets of evidence that have their own respective limitations (due to data quality) but that, when taken together, provide strong suggestive evidence that Troesken was correct. Economic freedom in the late nineteenth and first half of the twentieth centuries is associated with lower levels of typhoid fever mortality, while it has no discernable relationship with smallpox mortality. As typhoid fever caused substantially more deaths than smallpox, there are important lessons to be drawn regarding institutional responses to the COVID-19 pandemic.

Our paper is organized as follows. In Sect. 2, we distinguish two types of disease: diseases of poverty (such as typhoid fever) and diseases of commerce (such as smallpox and COVID-19). In Sect. 3, we consider institutional bundles and the implications for fighting disease. In Sect. 4, we present our evidence using both international data and subnational data pertaining to the United States during the postbellum era. In Sect. 4, we also extend the American states results to other contemporary mortality causes and find that the relationship is generalizable. In Sect. 5, we point out that our suggestive results should provide fuel for further research to (a) further improve the testing of Troesken's hypothesis and (b) extend it to other 
cases by improving the range of data available regarding economic institutions in general and economic freedom in particular.

\section{Diseases of poverty and diseases of commerce in nineteenth-century America}

One way to divide diseases is into those that depend on poverty and those that depend on commerce. By commerce, we mean social interactions and hence the diseases that are associated with the movement of and intercourse among people. Diseases of poverty, such as typhoid fever, depend on the eradication of poverty, as substantial investments in capital are necessary to eradicate the disease. ${ }^{6}$ Waterborne diseases tend to be associated with poverty, as eradication depends on water sanitation, sewers, and municipal garbage services - all public goods that are more challenging to provide in lower-income areas. Malaria is another example, as draining swamps is a large-scale capital investment that depends in part on wealth (Bleakley, 2010). Diseases of commerce, in contrast, involve limiting the movement of people through measures such as closures of schools and businesses (for example, an economic lockdown), mandatory vaccinations and population tracking and include such diseases as smallpox.

As an example of a disease of poverty, following Troesken (2015), we consider the case of typhoid fever. The eradication of typhoid fever, like other waterborne diseases, depends on large-scale investments in infrastructure, in particular waterpurification technology. Water purification loosely fits with the notion of a public good, though it could be privately provided, depending on the technology for excluding people from its use (Carson, 2016, 2020; Troesken, 1999). ${ }^{7}$ Combating typhoid fever by investing in water treatment technologies has substantial benefits in terms of educational attainment and earnings later in life that justify the costs of adopting the technology (Beach et al., 2016). Combating typhoid fever does not require strict economic lockdowns or quarantines. Rather, the factor most likely to determine whether it can be controlled is whether the government or the private sector can afford to provide water sanitation and other related services, which in turn depends on average incomes.

Troesken (2015) points out that smallpox is an example of an infectious disease that depends less on poverty than on the ability of government to control the movement of people. Thus, it falls into the disease of commerce category. Smallpox wreaked havoc on human health for two millennia. The initial method of control was variolation, or purposefully infecting people with smallpox to give them immunity. By the early nineteenth century, variolation was replaced by vaccination,

\footnotetext{
6 There are diseases of poverty that are not infectious. For example, cardiovascular diseases are often considered to be diseases of poverty (Rosegren et al., 2019).

7 This is true of public goods in general, which can be privately provided when the costs of exclusion change. This necessitates consideration of markets as alternative solutions to governments in cases of "market failure" (Candela \& Geloso, 2021). The work of Carson that we cite concerns malaria prevention in the United States, which was the result of private actions rather than state actions.
} 
making smallpox a curable disease. Though there were smallpox vaccines by the early nineteenth century, outbreaks continued. According to Troesken, the main tool that governments had to access to during the nineteenth century was the mandatory vaccinations which, nevertheless, required important coercive measures given the technological constraints of the era. As an example of the coerciveness required, the city of Boston mandated in 1901 the forced vaccination of the homeless because it suspected them of being the spreaders of smallpox (Albert et al., 2001). In other words, coercion was necessary to implement the restrictions mentioned above even with the availability of vaccines. More specifically, a government with no coercive ability would be unable to follow through with its edicts of quarantines, stay in place orders and lockdowns.

In the United States, both smallpox and typhoid fever persisted into the twentieth century. There were differences between them: death rates from smallpox were roughly one-eighth of those from typhoid fever in the United States circa 1880 and one-fifth circa 1900. However, the United States' mortality rate from smallpox in 1900 was above the average of Western countries and well above the level observed in countries with roughly the same income as the United States (Troesken, 2015, 97). Why the difference?

Troesken argues that the United States' constitution imposed several barriers on state governments seeking to implement strategies whose efficiency was well documented, such as mandatory vaccinations. The most notable reasons were that the purview of such strategies was supposed to lie with state governments (i.e. federalism) and that state and local governments had to expressly enact such laws (and face electoral consequences).

The constitutional emphasis on federalism meant that a state could choose a path that might adversely affect neighboring states. For example, imagine that Louisiana's legislature chooses to do nothing to prevent the spread of a given infectious disease. This inaction, given the important trading hub at New Orleans, will turn Louisiana into an entry point for diseases, which will then spread to Arkansas, Mississippi, and Texas. Alternatively, if Louisiana adopts preventive measures, those neighboring states can free ride on its efforts.

Second, states had to create their public health agencies and vest them with unambiguous powers to mandate certain behaviors. That meant that certain state bodies were precluded from acting even if they had some tools at their disposals to mandate certain behaviors. For example, school boards could not exclude unvaccinated children unless they were explicitly given that power by legislation. That meant bringing such policies to the floor of legislature, where rent-seeking, logrolling, and political self-interest could lead to the defeat of any proposal.

Taken together, these two features of the American constitutional order meant that the United States could not deploy the highly effective tools (such as mandatory vaccinations to fight smallpox) that other nations could (such as Prussia, Norway and Denmark). However, Troesken (2015) points out that there was a positive flipside to these restrictions on enacting smallpox-prevention policies, in two respects. First, the United States' commitment to federalism was "market-preserving" because it forced policy competition among the states (Weingast, 1995). Second, the barriers to state actions also effectively increased the protection for property rights. This 
flipside allowed the United States to grow rich and generate a second-order effect on health outcomes: by making Americans richer, these institutional features also allowed investments in other health goods that would later reduce mortality. The main example that Troesken uses is the case of typhoid fever, where the combination of wealth and secure property rights allowed the necessary investments in watertreatment facilities to be made.

Simply put, Troesken advances an institutional theory of disease burden. However, it is largely geared toward explaining the oddity of the American situation (rich with high rates of smallpox deaths). It is not directly tied to broader institutional concepts such as economic freedom-something that we attempt to remedy in the next section.

\section{Economic freedom, bundling, and disease burden}

Can Troesken's hypothesis be generalized beyond the historical case of nineteenth century America? We argue that it indeed can be. Essentially, Troesken's hypothesis is one in which secure property rights have different effects on the incidence and death rates of different diseases. When secured, property rights may increase smallpox death rates by prohibiting government policies that require curtailments of property rights. Simultaneously, they reduce typhoid fever death rates thanks to their positive effect on growth. Replacing "smallpox" by diseases of commerce and "typhoid fever" by diseases of poverty does not alter the theory.

In fact, the hypothesis can be augmented to speak directly to economic freedom as property rights are a key component of existing economic freedom indexes. From this, a clear empirical prediction can be made. Assuming ideal data (large number of observations for relevant covariates) and the ability to wade through any issue of endogeneity, ${ }^{8}$ we should observe that economic freedom reduces mortality from diseases sensitive to income levels (for example, typhoid fever) and has either no effect or even a positive effect on diseases of commerce (for example, smallpox).

Consider first diseases of poverty. Wealthier communities are more likely to make investments in improving water quality. Thus, economic freedom, which contributes to greater wealth, is likely to contribute to provision of public goods and to reduce the burden of diseases such as typhoid fever whose mitigation is largely a function not of coercion but of having the resources to pay for public goods. If the investments are not public goods (that is, markets will not underprovide them), the effects are the same. This is because they are still immovable capital goods that require large initial outlays and take a long time to mature. Large fixed costs, immovability, and long maturities are deterrents to investments in insecure property rights environments, as governments could seize the capital goods and offer little to no

\footnotetext{
${ }^{8}$ Geloso and Bologna Pavlik (2021) and Candela and Geloso (2021), in considering the effects of pandemics on economic growth, were able to deal endogeneity by considering influenza-pandemic episodes from 1857 to 2000 in which governments did not provide any strong policy responses. They argue that the level of pandemic mortality was independent from the changes in economic freedom. However,
} 
compensation. In secure property rights environments, these investments can be made. In any case, economic freedom should be associated with a smaller disease burden from these sources.

A disease associated with the free movement of people, such as smallpox or COVID-19, is different. Economic freedom may be significant, as imposing restrictions on people and their businesses creates economic harms. The more robust property protections are, the less likely it is that governments will impose coercive measures to clamp down on the movement of people and on economic activities. Thus, economic freedom may allow the disease to run unchecked. Empirically, we expect economic freedom to be associated with a greater burden from such diseases. As we pointed out in the introduction, McCannon and Hall (2021) and Geloso and Murtazashvili (2021) provide evidence that economically free states/nations reacted more slowly and less aggressively to the pandemic (all else being equal).

We now return to the idea of bundling. When institutions are selected, economic agents face a wide array of diseases which implies an equally wide array of tradeoffs. A country that chooses a bundle with substantial economic freedom is richer, better tooled to combat diseases of poverty, but less able to counter diseases associated with the free movement of people. In contrast, a country with low economic freedom will be poorer, ill-equipped to combat diseases of poverty, and potently prepared to combat diseases linked to social interactions.

The implications for COVID-19 are clear. Economic freedom could reduce a country's ability to diseases of commerce such as COVID-19, as the bundle that produces wealth is likely to have some policy-implementation costs. It could even exacerbate the effects by letting the disease run free. Thus, we could expect a positive statistical association between diseases of commerce and economic freedom.

However, there are notes of caution to make to avoid a misstatement of the institutional-bundle case. First, the literature on economic freedom show that the component of economic freedom that speaks to the size of government as a share of GDP behaves somewhat differently from the other components (Heckelman \& Stroup, 2000). Indeed, there are many countries that exhibit both high levels of government spending and high levels of economic freedom (which means that such countries score higher on the non-spending components of economic freedom indexes) and perform quite well in terms of economic growth. ${ }^{9}$ To explain this anomaly, Bergh (2020) make a distinction between types of big government. One type is a large fiscal state that engages only in simple forms of income redistribution. Such a state tends to intervene very little in the functioning of the market beyond the tax revenues it raises. The other type is a more interventionist state that tries to shape and direct market outcomes. Such states can be relatively small in fiscal terms but cause tremendous harm by its violations of property rights and weaker rule of law. Bergh (2020) argues that many of the former type of state tend to be fiscally large but strongly committed to the rule of law. For our purposes, this note of caution allows

\footnotetext{
9 This also explains why, when the component for government spending in excluded from the indexes, the effects of economic freedom on outcomes such as life satisfaction are clearer and stronger (Ott, 2018).
} 
us to emphasize that it is property rights that matter most directly to Troesken's argument, not the fiscal size of governments. In fact, if property rights stimulate growth and health is considered a luxury good, property rights could indirectly fuel more public expenditures on health. This last point leads to our claim that we should not overstate the potentially positive association as economic freedom may also produce the seeds of mitigation for diseases of commerce in the long run. Indeed, our case is that economically free regimes tend to be unable to adopt heavy-handed policies. As a result, the mix of mortality causes is going to be skewed in favor of diseases of commerce in economically free countries. However, it does not automatically follow from this that the overall level of mortality from each cause is going to be a higher in economically free nations. To see this distinction, consider how prosperity may make it possible, following Bergh's (2020) logic, for larger fiscal states to spend more on health care. In such a situation, well-secured property rights would permit more spending on treating diseases of commerce once contracted while also reducing diseases of poverty thanks to economic growth. This would reduce the level of mortality from both causes even if this liberal democracy cannot deploy heavy-handed measures in the face of diseases of commerce. The mix would thus be skewed in favor of diseases of commerce even if the level is lower.

It is also worth pointing out that if Bergh (2020) is correct in stating that large fiscal states can commit credibly to the rule of law, there could be temporary declines in economic freedom during crises. Thus, the long-term commitment to secure property rights would allow governments to temporarily invoke powers which, for less trustworthy regimes, would not generate the adverse trade-offs highlighted by Troesken (2015). However, given the results of McCannon and Hall (2021) regarding state-level lockdowns and economic freedom in the United States (see introduction) and the empirical literature on the ratchet effect of crises on the scale and scope of government (Higgs, 1987; O'Reilly \& Powell, 2015; Coyne and Hall, 2018), we are skeptical of whether such short-run variations are only transitory. We thus prefer to emphasize the mechanisms we underline in this paragraph. In addition, the majority of the most aggressive stay-at-home orders happened before most places had actually seen significant spread of the virus (since they occurred in March, when the burden of COVID cases was still largely localized to the NY/NJ/PA tri-state area), so they could not have been a response to actual local incidence of COVID cases or deaths. Although one could still say that the orders are related to expected future cases/ deaths in an area, and if those expectations were accurate, that would be an analogous reverse causality type of story, such an argument requires strong assumptions.

Heightening this distinction between level and mix are the relationships between both types of diseases due to comorbidities. For example, the top five comorbidities from COVID-19 (which we can consider a disease of commerce) are (ordered by fatality rate) obesity, liver diseases, kidney diseases, chronic obstructive pulmonary disease and cardiovascular diseases (Ejaz et al., 2020). While some studies find comorbidities such as obesity are positively associated with economic growth (Egger et al., 2012), others such as kidney disease tend to fall with income (McKinley et al., 
2020). ${ }^{10}$ If the diseases of poverty make people more vulnerable to diseases of commerce, economic freedom (by promoting economic growth) may indirectly reduce diseases of commerce by reducing comorbidities associated with poverty, even if it also constrains states' ability to deploy public health measures due to well-protected property rights. In other words, the relation between economic freedom and diseases of commerce could still be positive but of a smaller magnitude because of the two mitigating forces we mention.

\section{Evidence}

To formally test our augmentation of Troesken's framework, we present different two sets of supporting evidence. Each set is plagued by data limitations so that neither alone constitutes a smoking gun. However, taken together, they appear to confirm Troesken's argument: all else being equal (including income where possible) economic freedom in the late nineteenth century and mid-twentieth century were associated with lower levels of typhoid fever deaths but displayed no relationship with infectious diseases such as smallpox. We break the present section into two subsections: international evidence (circa 1900 and 1950s) and evidence from American states (for the late nineteenth century).

\subsection{International evidence from the first half of the 20th century}

One would expect the most variations in institutions to be among countries rather than within countries. Unfortunately, this source of variation does not lend itself easily to analysis for the end of the nineteenth century-which is the period that Troesken used to make his case. There are two reasons for this. We explain each of these reasons below.

The first relates to the paucity of indicators regarding the quality of economic institutions. Normally, researchers rely on the Fraser Institute's Economic Freedom of the World (EFW) index to measure these institutions. Unfortunately, that index only starts in 1950 (Hall \& Lawson, 2014; Murphy \& Lawson, 2018). Because of that limitation, Prados de la Escosura (2016) generated the Historical Index of Economic Liberty (HIEL), which covers the period from 1850 onward. That dataset is ideally suited for our purposes, as its methodology is very similar to that of the EFW. The main difference is that HIEL does not include a component for the size of government. The other components (regulation, property rights, international trade,

\footnotetext{
10 A good contemporary example is that of the Navajo Nation in America. During the COVID-19 pandemic, it exhibited infection and mortality rates significantly higher the rest of the country. The reasons reflect the lower levels of economic development on reservations, which are the poorest group in the country (Crepelle \& Murtazashvili, 2020). Thus, while economic freedom is limited on reservations (Alston et al., 2021), which may influence pandemic response (for example, making lockdown easier to implement), when the disease hit, it was much more deadly because poverty causes increases in the comorbidities.
} 
and sound money) are, however, similar. The downside of HIEL for our purposes is that it includes only twenty countries. This imposes an important limitation on the sample size. There exist other measures of institutional quality for the nineteenth century such as the Polity V index (see also Rånge \& Sandberg, 2017), but they speak to political institutions rather than economic institutions. Accordingly, we are constrained to a maximum sample size of the twenty countries in the HIEL dataset.

The second reason is that while there are datasets that compare aggregate mortality rates (with some caveats) across large numbers of countries circa 1900, international comparisons of cause-specific mortality rates are much scarcer. They are also not assembled in a single usable source so that researchers must assemble the evidence by consulting the statistical yearbooks of the different countries. The problem is that they are not always comparable. For example, the statistical yearbooks for France provide the death count from typhoid fever but only for urban areas with more than five thousand inhabitants. To address this explicitly, we present a crosscountry analysis using the earliest available data that includes a larger number of countries and ensures comparability of cause-specific measurements across countries, which is from the $1950 \mathrm{~s}$.

To be sure, these are the same limitations as those faced by Troesken, who was able to assemble evidence on only twenty-eight countries circa $1900 .{ }^{11}$ Nevertheless, using these different yearbooks and other government publications, we were able to collect smallpox death rates for nineteen of the countries in the HIEL dataset circa 1900. For typhoid, we were able to collect death rates for sixteen of the countries in the HIEL dataset circa 1900. These data are described in Table 1, and the source materials are discussed in the supplements to this article. We also followed the same strategy as Troesken in attempting to control for whether a country was predominantly Catholic, as members of this religion were generally more opposed to vaccination efforts (Troesken, 2015: 98).

In Table 2, we produce the results from an OLS regression. Specifications (1) and (3) provide supportive evidence for our contention that economic freedom matters more for typhoid fever than it does for smallpox: the effects of HIEL are statistically significant (at the 5 percent level) for the former but not the latter. In specifications

Table 1 Descriptive statistics for international evidence, circa 1900

\begin{tabular}{llllcc}
\hline Variable & Obs & Mean & Std Dev & Min. & Max. \\
\hline Log of typhoid death rate & 16.00 & 2.85 & 0.69 & 1.84 & 4.12 \\
Log of smallpox death rate & 19.00 & 0.07 & 1.84 & -2.30 & 3.29 \\
Economic liberty (HIEL), 1900 to 1905 average & 20.00 & 8.55 & 0.56 & 7.20 & 9.32 \\
Catholic dummy & 20.00 & 0.30 & 0.47 & 0.00 & 1.00 \\
Log of GDP per capita 1900 to 1905 average & 20.00 & 8.24 & 0.47 & 7.36 & 8.82 \\
\hline
\end{tabular}

11 Moreover, two of these observations were for England and Scotland rather than for the United Kingdom as a whole. 
Table 2 OLS results with smallpox and typhoid fever death rates, circa 1900, international

\begin{tabular}{|c|c|c|c|c|}
\hline \multirow[t]{2}{*}{ Variables } & (1) & (2) & (3) & (4) \\
\hline & $\begin{array}{l}\text { Log of smallpox } \\
\text { death rates }\end{array}$ & $\begin{array}{l}\text { Log of smallpox } \\
\text { death rates }\end{array}$ & $\begin{array}{l}\text { Log of typhoid fever } \\
\text { death rates }\end{array}$ & $\begin{array}{l}\text { Log of typhoid } \\
\text { fever death } \\
\text { rates }\end{array}$ \\
\hline \multirow{2}{*}{$\begin{array}{l}\text { Economic liberty } \\
\text { (HIEL), } 1900 \text { to } \\
1905 \text { average }\end{array}$} & -0.309 & -0.0303 & $-0.811 * *$ & $-1.012 * *$ \\
\hline & $(0.479)$ & $(0.691)$ & $(0.352)$ & $(0.392)$ \\
\hline \multirow[t]{2}{*}{ Catholic dummy } & $2.798 * * *$ & $2.784 * * *$ & $0.577 *$ & $0.604^{*}$ \\
\hline & $(0.589)$ & $(0.590)$ & $(0.284)$ & $(0.278)$ \\
\hline \multirow{2}{*}{$\begin{array}{l}\text { Log of GDP PC, } \\
1900 \text { to } 1905 \\
\text { average }\end{array}$} & & -0.546 & & 0.512 \\
\hline & & $(0.884)$ & & $(0.291)$ \\
\hline \multirow[t]{2}{*}{ Constant } & 1.842 & 3.972 & $9.767 * * *$ & $7.233 * *$ \\
\hline & $(4.276)$ & $(4.837)$ & (3.196) & $(2.985)$ \\
\hline Observations & 19 & 19 & 16 & 16 \\
\hline R-squared & 0.592 & 0.604 & 0.513 & 0.583 \\
\hline
\end{tabular}

Robust standard errors in parentheses

$* * * p<0.01, * * p<0.05, * p<0.1$

(2) and (4), we added the log of income per capita to control for differences in economic development. Our result remains unchanged.

Subject to the caveats we mentioned above, these limited results appear to be economically significant. The coefficients for HIEL on typhoid death rates are large, and death rates from typhoid were four times greater than deaths from smallpox for the average country. This suggests that economic liberty's palliative effects are focused more heavily on the larger source of mortality.

We can extend this international comparison to the 1950s. In that decade, there were still 50 million cases of smallpox per year (Chittick et al., 2017) and deaths from typhoid fever were orders of magnitude more numerous in the countries for which we have data. This is the farthest we can go to reliably test the claim of Troesken, as in 1959, the World Health Organization adopted its resolution to eradicate smallpox. Later, in 1966, the Eradication Program was launched and by 1977 the disease was eradicated. It is also the earliest decade we can use if we want to increase the sample size to include values of economic freedom for poorer countries. The HIEL dataset only considers close to two dozen rich countries continuously. The first year for which we have a sample of economic freedom estimates that includes more poor countries is 1950 thanks to an extension of the EFW index produced by Murphy and Lawson (2018). We averaged the values of for 41 countries that provide information about death rates from smallpox, typhoid fever, GDP per capita and economic freedom over the decade of the 1950s. Death rates were calculated using annual cause-specific death counts by country from the World Health Organization (WHO) Mortality Database and annual population estimates by country from the United Nations World Population Prospects database. Table 3 shows the descriptive statistics for this sample. 
The results, shown in Table 4, point in the same direction as those in Table 2. The coefficient for EFW on smallpox is not significant regardless of the specification used below. However, the coefficient of EFW on typhoid fever death rates is significant and negative as we expect. This latter result holds regardless of whether we include income as a control variable or not. While it points in the same direction, we want to be careful here. The data we collected for smallpox deaths that were used in Table 2 were more accurate. The data for poor countries regarding smallpox, even by the 1950 s, has some shortcomings as the cases are known to have been underenumerated (Fenner et al., 1988: 175). While the ranking of countries in terms of smallpox deaths appears accurate (as most rich countries had nearly eradicated smallpox), the mortality count for some poor countries may be underestimated. However, the same problem exists for typhoid fever deaths so that, if the count differences were considerable for both diseases equally, our results should be affected for typhoid fever as well. As they are not and remain similar to those in Table 2, we are comfortable with the pattern of our findings.

Table 3 Descriptive statistics for international evidence, $1950 \mathrm{~s}$

Table 4 OLS results with smallpox and typhoid fever death rates, 1950s, international

\begin{tabular}{llllll}
\hline Variables & $(1)$ & $(2)$ & $(3)$ & $(4)$ & $(5)$ \\
& $\mathrm{N}$ & Mean & Sd & Min. & Max. \\
\hline Economic freedom & 41 & 5.523 & 0.735 & 3.690 & 6.931 \\
Log of GDP per capita & 49 & 8.547 & 0.739 & 6.782 & 9.752 \\
Catholic dummy & 58 & 0.362 & 0.485 & 0 & 1 \\
Log of smallpox death rate & 58 & 0.00331 & 0.0199 & 0 & 0.151 \\
Log of typhoid death rate & 58 & 0.129 & 0.190 & 0.00231 & 0.811 \\
\hline
\end{tabular}

\begin{tabular}{lll}
\hline Variables & $\begin{array}{l}\text { Log of typhoid fever } \\
\text { death rates }\end{array}$ & $\begin{array}{l}\text { Log of small- } \\
\text { pox death } \\
\text { rates }\end{array}$ \\
\hline Economic freedom & $-0.114^{* *}$ & -0.00260 \\
Log GDP per capita & $(0.0454)$ & $(0.00557)$ \\
Catholic dummy & $-0.0854^{* *}$ & -0.00356 \\
Constant & $(0.0364)$ & $(0.00238)$ \\
& 0.0750 & 0.00573 \\
Observations & $(0.0553)$ & $(0.00691)$ \\
R-squared & $1.491 * * *$ & 0.0470 \\
\hline
\end{tabular}

Robust standard errors in parentheses

$* * * p<0.01, * * p<0.05, * p<0.1$ 


\subsection{Evidence from American States}

The international evidence assembled has limitations because of the small number of cases. To alleviate this, we consider data from the United States, which provides an additional opportunity to evaluate the relationship between economic freedom and disease. While American states capture fewer variations in economic freedom than what would be seen across countries, there are important variations at the subnational level that could still be of relevance.

To get information on variation among the states, there is a new and useful dataset at our disposal. It is a direct measure of economic freedom in American states that include the census years from 1850 to 1890 produced by Murphy and Stansel (2019)-which we will refer to as the EFUSA. ${ }^{12}$ Normally, subnational estimates of economic freedom follow the strategy of the Economic Freedom of North America (EFNA) index produced by the Fraser Institute. That index has three components: government spending, taxes, and labor regulation. However, for the EFUSA, Murphy and Stansel (2019) tried to make the states more comparable with countries, and so they added an inflation measure and a tariff measure. Obviously, these two measures are national measures that are embedded in the index, which has the effect of attenuating variations among states. However, this is a bias that works against us, as variations are artificially muted. Moreover, we expect the effects of economic freedom on mortality would be greater between countries than within countries. As such, the effects of economic freedom-all else being equal-should be more muted as well within countries which means that this subnational approach is biased against finding any effect. Finally, there is some evidence that the EFUSA is inversely correlated with the stringency of measures to deal with smallpox and with the security of property rights relevant to the production of water treatment infrastructure necessary to deal with typhoid fever ${ }^{13}$ (Fig. 1).

The main data issue that calls for caution concerns the quality of the mortality data. McGuire and Coelho (2011: appendix C) compiled all the state-level estimates of mortality reported by the censuses from 1850 to 1900 . These include cause-specific death rates. However, it is generally admitted that the census mortality data are

\footnotetext{
12 The database of economic freedom constructed by Murphy and Stansel (2019) suggests that the level of economic freedom was consistent during the 1850 to 1890 period with a dip following the Civil War (the mean index for states fluctuates between 6.08 and 6.62 during the period). The movements are similar for most states and most of the variance is across units rather than over time (see footnote 15 for supplementary results that rely on a panel approach which include state-specific time-trends).

13 There is no systematic assessment or ranking of the stringency of smallpox related policies for American states in the nineteenth century. Most of the assessments of such policies are is for the post-World War I era - after the progressive era reforms changed the nature of governments in the USA. However, an 1894 reference handbook (Buck 1894: 554) contains a partial listing of laws regarding vaccination in 27 states. States that had compulsory vaccinations, local ordinances (such as New Orleans), school exclusion for non-vaccinated exhibited a lower level of EFUSA in 1890 than those that had no such laws (6.11 versus 6.32 which is roughly half of the standard deviation for those states). With regards to water infrastructure, Troesken is abundantly clear - investments depended on the risks of expropriation without proper compensation at the local level especially given the costliness of litigation (Troesken, 2015: 126-127).
} 


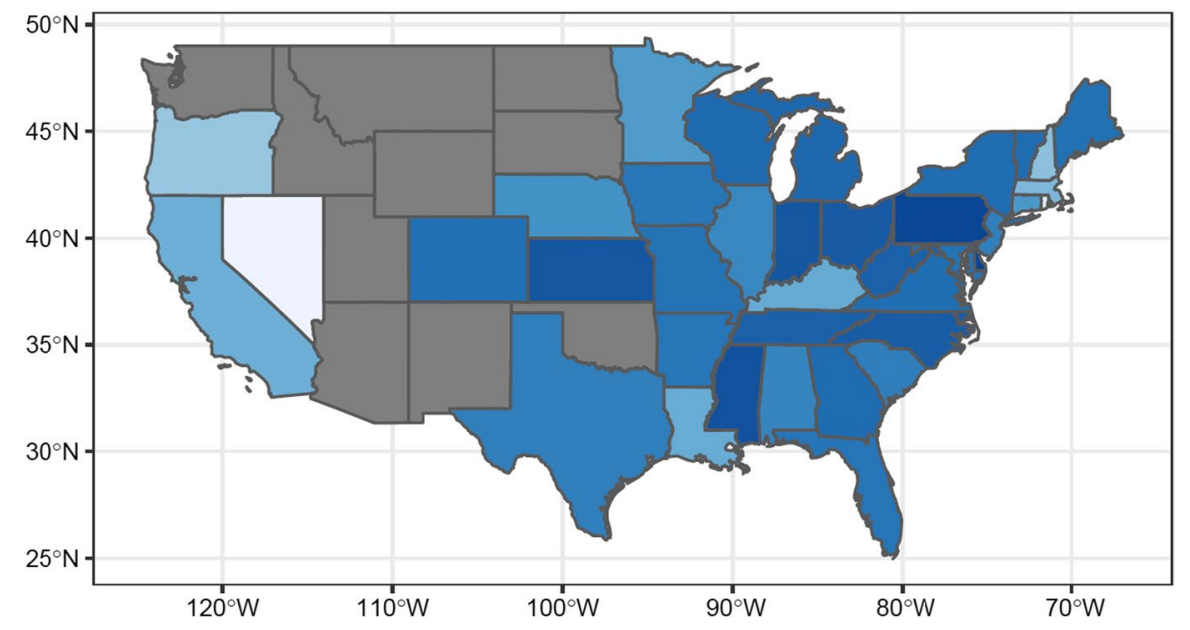

EFUSA in 1880

$\begin{array}{llll}5.0 & 5.5 & 6.0 & 6.5\end{array}$

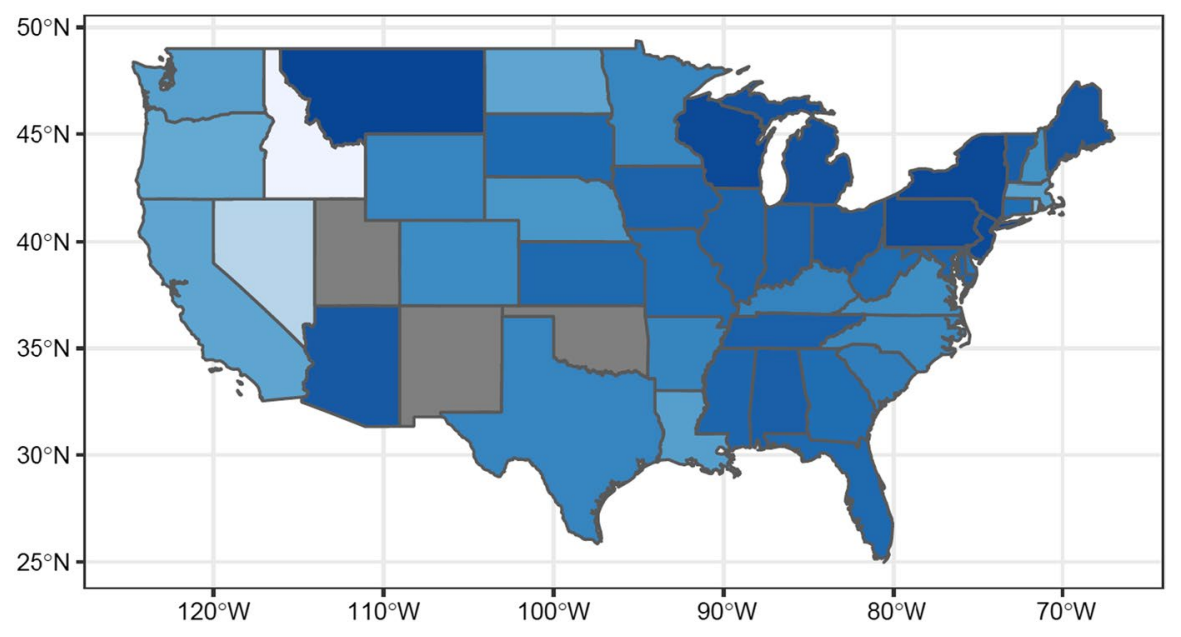

Average EFUSA, 1850-1890

$4 \quad 5 \quad 6$

Fig. 1 EFUSA, 1880 (top panel) and average EFUSA for 1850-1890 (bottom panel) 
flawed because they undercount deaths so that the levels are somewhat implausibly low (Condran \& Crimmins, ; Higgs, 1979; Higgs \& Booth, 1979). ${ }^{14}$ That problem is particularly acute for deaths of infants, who tended to be more vulnerable to smallpox and typhoid fever (McGuire \& Coelho, 2011: 239). However, the relative levels of mortality among states are more accurate so that the undercounting affects states more or less equally (McGuire \& Coelho, 2011: 239; Yasuba, 1962) even if there are still concerns (Condran \& Crimmins, 1979). At first glance, the data appear to permit a panel approach, but this is impossible because the relative level of quality between censuses is unstable, which creates problems for panel estimation. ${ }^{15}$ Accordingly, we are forced to use a cross-sectional approach. Fortunately, McGuire and Coelho (2011: 238) point out that "the 1880 mortality census [is] the most complete of the six censuses." As a result, we are most confident in any evidence pertaining to the 1880 census even if we remain cautious.

The most important control variables relate to the population's age. This will speak to the likely vulnerability of the local population (and thus the costs of outbreak). Smallpox and typhoid fever have particularly high death rates among the youngest (below fourteen and especially below age nine). Other demographic variables of relevance are the share of the population that is foreign born (as they had higher death rates, especially among infants-see Higgs \& Booth, 1979), whether a state used to be a slave state (in order to capture the living conditions of the African American population and its potential effects on economic freedom), and the urbanization rate, which captures the infectious aspect of the diseases. As typhoid is a waterborne disease, we also include an indicator for the availability of water sources (which will speak to how much intervention is needed). ${ }^{16}$ However, we do not use this variable for smallpox as water supply is not a relevant determinant in the incidence of smallpox. ${ }^{17}$ We also use a variable to capture the supply of medical

\footnotetext{
14 This was a generalized problem of census-based efforts to record mortality (see notably Pelletier et al., 1997 for an application to Canada in the nineteenth century).

15 For example, the 1870 census is deemed to be the worst of all the six censuses from 1850 to 1900 while the census of 1880 is deemed the best. Any panel estimation would thus face a bias because of measurement error, which would lead to an underestimation of the change in mortality between the two censuses (that is, the undercounting problem is greater in 1870 than 1880). A year fixed effect would not fully resolve the issue, as it would capture both time effects and census effects. To circumvent the issue, we tried a panel approach that includes a state-specific time trend. In that setting, the year-fixed effects capture the census-related measurement problems and the time-trend specific to each state are supposed to capture the effects of time. This is imperfect as it does not directly deal with varying census quality, but it does approximate this. The year-fixed effects assume that the problem is inherent to the entire country. The time-effects are specific to each state. This is imperfect but it also allows us to use state-fixed effects to control for any unobserved heterogeneity between states. We find the same results as those we find below: economic freedom reduces the log of typhoid fever deaths while it has no significant effect on the log of smallpox deaths. The results hold if we exclude the census of 1870 . They also hold if we keep the sample balanced over time. Results available are available in online supplementary materials at https://vincentgeloso.files.wordpress.com/2021/04/ejle-appendix-pdf.pdf.

16 The census of 1880 provides a breakdown of the area of the different states including the water sources. We used that breakdown, subtracted coastal waters (which would be saline and thus unsuited for human consumption), and expressed it as a ratio to the state's population.

17 However, including it does not alter our results.
} 
Table 5 Descriptive statistics for 1880 census

\begin{tabular}{lrrrrr}
\hline Variable & Obs & Mean & Std Dev & Min. & Max. \\
\hline Log of typhoid death rate & 46.00 & 1.37 & 0.39 & 0.05 & 2.02 \\
Log of smallpox death rate & 44.00 & -1.68 & 1.04 & -2.30 & 2.63 \\
EFUSA, 1880 & 38.00 & 6.34 & 0.49 & 4.82 & 6.90 \\
Population up to 15 & 46.00 & 36.75 & 6.60 & 24.25 & 45.95 \\
Population below 9 & 46.00 & 26.05 & 4.92 & 17.52 & 33.72 \\
Proxy for water supply & 47.00 & 3.35 & 5.59 & 0.03 & 19.66 \\
Foreign-born-population share & 47.00 & 15.64 & 12.24 & 0.30 & 41.20 \\
Former slave state & 51.00 & 0.41 & 0.50 & 0.00 & 1.00 \\
African American population share & 45.00 & 12.74 & 18.94 & 0.16 & 60.70 \\
Urbanization rate & 46.00 & 23.08 & 18.00 & 3.06 & 81.95 \\
Physicians to population & 47.00 & 1.76 & 0.74 & 0.67 & 5.74 \\
Population density & 47.00 & 153.33 & 782.86 & 0.21 & 5394.63 \\
\hline
\end{tabular}

services: the number of physicians relative to population size. This is our baseline specification.

As a robustness check, we try swapping some of the variables for substitutes that serve the same purpose as those enumerated above. For example, we replace the former-slave-state variable with the share of the population that is African American and replace the share of the population below fourteen by the share of the population below nine. We also add population density alongside urbanization to capture the ease of spread of disease. All of these variables are described in Table 5. We use the $\log$ of death rates for the two diseases as our dependent variables. ${ }^{18}$

In Tables 6 and 7, we show the OLS results of these varying specifications. Economic freedom has a consistently significant effect on typhoid death rates (at the 10 percent level) regardless of the specification used. ${ }^{19}$ The baseline specification (column 1) offers the largest coefficient on economic freedom, but the coefficients obtained in other specifications are very close. However, economic freedom has no significant effect on smallpox death rates, though the coefficient is positive regardless of the specification used. To give an idea of magnitudes, let's look at what it means for the state with the lowest economic freedom and that with the

\footnotetext{
18 To circumvent the issue that some states had zero smallpox deaths, we added 0.1 to the rate before converting to logarithm. However, when we used the non-log form of death rates, all the results for typhoid fever are the same (in fact, significance improves). The results for smallpox are unchanged. We also tried using the inverse hyperbolic sine transformation $\left(\log \left(y_{i}+\left(y_{i}^{2}+1\right)^{\frac{1}{2}}\right)\right)$ to express our variable differently (see Bellemare \& Wichman, 2020). Our results are unchanged.

19 When we used the level rather than the log of death rates, the significance of economic freedom improves and is often significant above the 5 percent level. We also attempted to exclude the number of physicians to population as this could be construed as a bad control as economic freedom could increase the supply of physicians thus reducing mortality. The results are unaffected by the removal of this variable. This is consistent with the weak correlation (-0.07) between economic freedom and the supply of physicians. The correlation is weak for all years. Regression tests also show no statistically significant effects of EFUSA on supply of physicians when controls are added.
} 
highest typhoid fever mortality. If the state with the lowest economic freedom in 1880 (Nevada) moved to the average state's level of economic freedom, its death rate from typhoid fever would have gone from 2.9 per 100,000 to 1.6 per 100,000. If the state with the highest typhoid fever death toll (Indiana) had experienced an increase in economic freedom of one standard deviation ( 0.49 points), its death rate would have fallen from 7.4 deaths per 100,000 to 6.3 deaths per 100,000 .

As we pointed out, the quality of the censuses is quite uneven, which makes poses problems when pooling them into a panel to examine the relationship between economic freedom and disease burden in nineteenth-century America. To be sure, we did attempt a panel approach with the inclusion of fixed effects. This has the benefit of controlled for unobserved heterogeneity between states and increasing the sample size. The results are identical to those described using the highest-quality data for 1880: economic freedom reduces typhoid deaths but has no effects on smallpox deaths. These results are discussed in footnote 15 and are available in the online supplementary materials. A second way to assess robustness is to take the other censuses separately to see if the relationship hold from census to census. Using the model in the first columns of Tables 6 and 7, we replicated the exercise for the other census years that McGuire and Coelho (2011) compiled. The results are presented in summary form in Table $8 .{ }^{20}$ In four out of five censuses, economic freedom has a statistically significant negative effect (sometimes at the 5 percent level and sometimes at the 10 percent level) on typhoid death rates. The only census for which there is no discernible effect is that of 1870, which is unsurprising, as McGuire and Coelho point out that it was the "least complete" of the censuses between 1850 and 1900 (2011: 238). For smallpox death rates, the same pattern as in Table 5 is found: no discernible relationship between economic freedom and smallpox mortality. ${ }^{21}$

Overall, our finding appears robust given the limited pool of data: economic freedom is associated with lower death rates from typhoid fever but has no discernible effect on smallpox.

\footnotetext{
${ }^{20}$ The descriptive statistics for the censuses of $1850,1860,1870$, and 1890 are provided in our supplementary materials at https://vincentgeloso.files.wordpress.com/2021/04/ejle-appendix-pdf.pdf.

${ }^{21}$ For both smallpox and typhoid fever deaths, the $\mathrm{R}^{2}$ falls from census to census. One possible explanation is that that the explanatory power of the control variables is exaggerated in earlier censuses because those control variables are better at predicting ascertainment than they are at predicting actual mortality. If, for example, more urbanized states did a better job of counting smallpox deaths in 1850, 1860, and 1870, that would exaggerate the positive correlation between smallpox deaths and urbanization, and thus including urbanization in the regression would more dramatically increase $R^{2}$. Then in 1880 , the $R^{2}$ drops because the differences in ascertainment are less pronounced and thus the predictive power of the controls is reduced. Another possibility is that we are not capturing the level of medical knowledge that is evolving from census to census which is why the $\mathrm{R}^{2}$ would be falling without changing the relationship between the variables (because we expect a weak correlation between the omitted variable of "knowledge" and the controls).
} 
Table 6 OLS results on log typhoid fever death rates, 1880, American states

\begin{tabular}{|c|c|c|c|c|}
\hline \multirow[t]{2}{*}{ Variables } & (1) & (2) & (3) & (4) \\
\hline & Model 1 & Model 2 & Model 3 & Model 4 \\
\hline \multirow[t]{2}{*}{ EFUSA, 1880} & $-0.304^{*}$ & $-0.304^{*}$ & $-0.297^{*}$ & $-0.299 *$ \\
\hline & $(0.171)$ & $(0.174)$ & $(0.173)$ & $(0.173)$ \\
\hline \multirow[t]{2}{*}{ Population up to 15} & 0.0171 & 0.0172 & & 0.0168 \\
\hline & $(0.0124)$ & $(0.0119)$ & & $(0.0128)$ \\
\hline \multirow[t]{2}{*}{ Proxy for water supply } & -0.0340 & -0.0337 & -0.0352 & -0.0334 \\
\hline & $(0.0218)$ & $(0.0199)$ & $(0.0224)$ & $(0.0218)$ \\
\hline \multirow[t]{2}{*}{ Foreign-born-population share } & -0.00194 & -0.00191 & -0.00251 & -0.00130 \\
\hline & $(0.00586)$ & $(0.00682)$ & $(0.00624)$ & $(0.00705)$ \\
\hline \multirow[t]{2}{*}{ Former slave state } & 0.0162 & & 0.0111 & 0.0230 \\
\hline & $(0.161)$ & & $(0.174)$ & $(0.171)$ \\
\hline \multirow[t]{2}{*}{ Urbanization rate } & -0.00919 & -0.00916 & -0.00937 & -0.0101 \\
\hline & $(0.00575)$ & $(0.00561)$ & $(0.00598)$ & $(0.00826)$ \\
\hline \multirow[t]{2}{*}{ Physicians to population } & $0.232 *$ & $0.237 *$ & $0.222 *$ & $0.237 *$ \\
\hline & $(0.123)$ & $(0.132)$ & $(0.120)$ & $(0.135)$ \\
\hline \multirow[t]{2}{*}{ African American population share } & & 0.000481 & & \\
\hline & & $(0.00542)$ & & \\
\hline \multirow[t]{2}{*}{ Population below 9} & & & 0.0194 & \\
\hline & & & $(0.0170)$ & \\
\hline \multirow[t]{2}{*}{ Population density } & & & & 0.000328 \\
\hline & & & & $(0.00173)$ \\
\hline \multirow[t]{2}{*}{ Constant } & $2.615 *$ & $2.606^{*}$ & $2.734^{*}$ & $2.586^{*}$ \\
\hline & $(1.438)$ & $(1.416)$ & $(1.453)$ & $(1.456)$ \\
\hline Observations & 38 & 38 & 38 & 38 \\
\hline R-squared & 0.417 & 0.417 & 0.411 & 0.417 \\
\hline
\end{tabular}

Robust standard errors in parentheses

$* * * p<0.01, * * p<0.05, * p<0.1$

\section{Discussion and conclusion}

Credible economic analysis requires the comparison of real-world alternatives rather than comparisons with imagined Nirvanas (Demsetz, 1969). Our institutions-asbundles notion avoids the nirvana fallacy by recognizing that any given bundle of institutions involves trade-offs. Despite the trade-offs, we find that on balance, economic freedom allows for an optimal response to infectious diseases, particularly in 
Table 7 OLS results on log of smallpox death rates, 1880, American states

\begin{tabular}{|c|c|c|c|c|}
\hline \multirow[t]{2}{*}{ Variables } & (1) & (2) & (3) & (4) \\
\hline & Model 1 & Model 2 & Model 2 & Model 2 \\
\hline \multirow[t]{2}{*}{ EFUSA, 1880} & 0.0849 & 0.118 & 0.0702 & 0.0882 \\
\hline & $(0.217)$ & $(0.216)$ & $(0.220)$ & $(0.229)$ \\
\hline \multirow[t]{2}{*}{ Population up to 15} & 0.0139 & 0.0111 & & 0.0135 \\
\hline & $(0.0398)$ & $(0.0428)$ & & $(0.0409)$ \\
\hline \multirow[t]{2}{*}{ Foreign-born-population share } & 0.00128 & 0.00482 & 0.00122 & 0.00212 \\
\hline & $(0.0103)$ & $(0.00862)$ & $(0.0101)$ & $(0.0145)$ \\
\hline \multirow[t]{2}{*}{ Former slave state } & 0.0294 & & -0.0212 & 0.0393 \\
\hline & $(0.287)$ & & $(0.252)$ & $(0.313)$ \\
\hline \multirow[t]{2}{*}{ Urbanization rate } & 0.00577 & 0.00605 & 0.00760 & 0.00462 \\
\hline & $(0.00589)$ & $(0.00567)$ & $(0.00689)$ & $(0.0136)$ \\
\hline \multirow[t]{2}{*}{ Physicians to population } & 0.186 & 0.248 & 0.227 & 0.194 \\
\hline & $(0.379)$ & $(0.366)$ & $(0.387)$ & $(0.402)$ \\
\hline \multirow[t]{2}{*}{ African American population share } & & 0.00453 & & \\
\hline & & $(0.00512)$ & & \\
\hline \multirow[t]{2}{*}{ Population below 9} & & & 0.0329 & \\
\hline & & & $(0.0583)$ & \\
\hline \multirow[t]{2}{*}{ Population density } & & & & 0.000377 \\
\hline & & & & $(0.00398)$ \\
\hline \multirow[t]{2}{*}{ Constant } & -3.414 & $-3.726^{*}$ & -3.756 & -3.436 \\
\hline & $(2.245)$ & $(1.892)$ & $(2.390)$ & $(2.323)$ \\
\hline Observations & 36 & 36 & 36 & 36 \\
\hline R-squared & 0.022 & 0.028 & 0.036 & 0.022 \\
\hline
\end{tabular}

Robust standard errors in parentheses

$* * * p<0.01, * * p<0.05, * p<0.1$

Table 8 Effect of economic freedom (EFUSA) on log of typhoid fever death rate and smallpox death rates using different censuses

\begin{tabular}{llllll}
\hline Variables & $(1)$ & $(2)$ & $(3)$ & $(4)$ & $(5)$ \\
& 1850 & 1860 & 1870 & 1880 & 1890 \\
\hline Log of typhoid fever & $-0.352^{* *}$ & $-0.221^{*}$ & -0.0515 & $-0.304^{*}$ & $-0.146^{*}$ \\
& $(0.160)$ & $(0.123)$ & $(0.142)$ & $(0.171)$ & $(0.0779)$ \\
Observations & 31 & 33 & 37 & 38 & 44 \\
R-squared & 0.719 & 0.408 & 0.142 & 0.417 & 0.287 \\
Log of smallpox & -0.308 & 0.213 & -0.468 & 0.0849 & 0.0840 \\
& $(0.621)$ & $(0.187)$ & $(0.538)$ & $(0.217)$ & $(0.0679)$ \\
Observations & 26 & 27 & 36 & 36 & 43 \\
R-squared & 0.348 & 0.583 & 0.389 & 0.022 & 0.079 \\
\hline
\end{tabular}

Robust standard errors in parentheses

$* * * p<0.01, * * p<0.05, * p<0.1$ 
the historical case of typhoid and smallpox. Economic freedom is optimal in that it reduces mortality from the source of mortality that is largest and cheapest to deal with, rather than source that is smaller and costlier to deal with. It would be possible to reduce economic freedom to address the diseases that are costlier to fight and thus change the mix of causes of deaths, but that would come at the cost of more deaths from diseases that are cheaper to prevent.

We must, however, weigh our claims by the quality and extent of the data available. Thus, our results should be as a step forward but not the last step to be taken. The next step would be to collect more data to extend economic freedom datasets. This is important as we cannot easily separate economic freedom from the state capacity that is associated with government ability to restrict movements of people. Economists are increasingly willing to use state capacity as an explanation for prosperity (Piano, 2019). This includes the view that military capacity explains the prosperity of the West (Dincecco \& Onorato, 2017). However, as Geloso and Salter (2020) show, increasing state capacity occurred historically in response to the need to protect wealth from predatory competitors; thus, wealth creation contributes to state capacity. Accordingly, economic freedom is likely to contribute to wealth and, by giving rise to state capacity, improve the ability to fight disease on two margins: through the wealth effect and through the state-capacity effect, which influences the ability to provide public goods. Thus, while there is much information on state fiscal and military capacity in the very long run for the West, what is needed is more data on economic freedom during that period to understand the link between freedom, state capacity, and disease burdens. ${ }^{22}$

Nevertheless, we believe that our results offer a potent lure for future researchers. Indeed, there is a parallel between smallpox and COVID-19 that provides a clear illustration of our contention regarding the bundling of institutions. The United States has been criticized for its response to the outbreak. Part of the reason for those reasons may be related to economic freedom, but our historical analysis suggests that economic freedom did not have as much of an effect in addressing smallpox as Troesken's work suggests. Rather, the more direct impact of economic freedom may be to insulate people from diseases by alleviating comorbidities associated with death and hospitalizations, such as heart disease or kidney and liver disease. As several comorbidities depend in part on wealth-poorer people are more likely to suffer from them-economic freedom likely insulates people from disease to some degree (we do not claim full insulation).

What then might explain why the United States has higher death rates from COVID-19? We would likely need to look more carefully into politics and perhaps even culture to understand why. One feature of the United States is robust civil liberties. Civil liberties make imposing strict economic lockdowns more

\footnotetext{
22 Another data limitation is related to inequality (see Benitez et al. (2020) and Bertocchi and Dimico (2021) for discussion relevant to COVID-19). The distribution of income is related to vulnerability within the population. The problem is that inequality data for the nineteenth century is limited. Efforts in the future to expand on the Troesken hypothesis should include efforts to measure inequality better and include it as a relevant control.
} 
challenging. We have seen this with legal challenges to economic lockdowns in nearly every state in which they were implemented. Another feature is federalism, which allows for self-governance but also contributes to variation in the COVID19 response. Beyond political considerations in the form of federalism, there are legal constraints as well, as several state courts have struck down economic lockdown provisions or restricted the powers of state governors to restrict economic activities.

Cultural institutions may influence pandemic policy. Bazzi et al. (2021) find that one feature of the United States is that the experience with settling the frontier had an important long-run impact on political culture, influencing how much of a role the people want for their government. This culture of individualism could reduce support for coercive policies, as people do not want government in their lives. Indeed, Bazzi et al. (2020) found that COVID-19's impact depends in part on these sorts of cultural factors, with individualism increasing the rates of transmission of coronavirus. Still, to the extent there is a robust correlation between individualism and wealth (see, for example, Gorodnichenko \& Roland, 2017), the negative effects of individualism were to an extent offset by the indirect effects of individualism on pandemic vulnerability through its wealth effect.

Of course, the best response among imperfect alternatives to fight disease is an open question. Extreme responses may sow the seeds of institutional decay, ${ }^{23}$ which prevents future reductions of other diseases. For example, consider the possibility that the United States adopted more extreme measures to contain smallpox at the expense of economic freedom. Our findings suggest that a consequence of this would have been increased mortality from typhoid fever, a larger source of mortality which is cheaper to prevent. Such an increase may also have had negative effects that materialized later in time, as Beach et al. (2016) found that there were longterm gains in income from eradicating typhoid fever. In other words, attenuating the power of economic freedom's effect on diseases of poverty may further depress outcomes. This should not be dismissed casually, as mortality from noncommunicable diseases-which are more sensitive to income and economic development-constituted 74 percent of fatalities in 195 countries from 1980 to 2017 (Roth et al., 2018).

What about COVID-19? Losing a lot of economic freedom could lead to fewer COVID-19 deaths, but it would come at a potentially massive cost in the following decades. The current debates center on the optimality of policy in the short run. Optimality in the dynamic sense differs. The smallpox story suggests that we are veering toward a less desirable institutional bundle and that much of its effects will be realized decades from now. Compounding this is the ratchet effect, which suggests a larger role for government that further reduces economic freedoms.

Another significant consideration is the link between disease and comorbidities associated with diseases of commerce. While some freedoms suggest greater disease

\footnotetext{
${ }^{23}$ The work of Desierto and Koyama (2020) clarifies why the politically optimal pandemic policy may not be the socially optimal one using a formal model; Boettke and Powell (2021) explain the challenge of designing and implementing optimal pandemic policy from the perspective of information and incentive problems confronting political decision-makers.
} 
burden, we also see that if we have increasing wealth, we get less of the comorbidities and less of a disease burden. An increase in wealth, especially among Black Americans and Native Americans, would likely reduce the burden of the pandemic a great deal. Thus, while economic freedom could increase mortality from diseases of commerce, the positive wealth effects mitigate the vulnerability of any given individual to the coronavirus.

Supplementary Information The online version contains supplementary material available at https://doi. org/10.1007/s10657-021-09704-7.

Acknowledgements The authors wish to thank Alain Marciano, Jamie Bologna Pavlik, Rosolino Candela, Chris Coyne, Peter Boettke, Dean Stansel,Louis Rouanet and Raymond March. Geloso thanks Basil Hayden's Kentucky Bourbon for the support. All errors are our own.

\section{References}

Albert, M. R., Ostheimer, K. G., \& Breman, J. G. (2001). The last smallpox epidemic in Boston and the vaccination controversy, 1901-1903. The New England Journal of Medicine, 344(5), 375-379.

Alston, E., Crepelle, A., Law, W., \& Murtazashvili, I. (2021). The chronic uncertainty of American Indian property rights. Journal of Institutional Economics. https://doi.org/10.1017/S1744137420000636.

Bazzi, S., Fiszbein, M., \& Gebresilasse, M. (2021). Frontier culture: The roots and persistence of "rugged individualism" in the United States. Econometrica. https://doi.org/10.3982/ECTA16484.

Bazzi, S., Fiszbein, M., and Gebresilasse, M. (2020). Rugged individualism and collective (in)action during the COVID-19 pandemic. NBER: https://www.nber.org/papers/w27776.

Beach, B., Clay, K., Saavedra, M. H. The 1918 influenza pandemic and its lessons for COVID-19. The Journal of Economic Literature. (forthcoming).

Beach, B., Ferrie, J., Saavedra, M. H., \& Troesken, W. (2016). Typhoid fever, water quality, and human capital formation. Journal of Economic History, 76(1), 41-75.

Bellemare, M. F., \& Wichman, C. J. (2020). Elasticities and the inverse hyperbolic sine transformation. Oxford Bulletin of Economics and Statistics, 82(1), 50-61.

Benitez, J., Courtemanche, C., \& Yelowitz, A. (2020). Racial and ethnic disparities in covid-19: Evidence from six large cities. Journal of Economics, Race, and Policy, 3(4), 243-261.

Bergh, A. (2020). Hayekian welfare states: Explaining the coexistence of economic freedom and big government. Journal of Institutional Economics, 16(1), 1-12.

Bertocchi, G., \& Dimico, A. (2021). COVID-19, Race, and Gender (No. 811). GLO Discussion Paper.

Bleakley, H. (2007). Disease and development: Evidence from hookworm eradication in the American South. Quarterly Journal of Economics, 122(1), 73-117.

Bleakley, H. (2010). Malaria eradication in the Americas: A retrospective analysis of childhood exposure. AEJ: Applied Economics, 2(2), 1-45.

Boettke, P., \& Powell, B. (2021). The political economy of the COVID-19 pandemic. Southern Economic Journal, 87(4), 1090-1106.

Buchanan, J.M. (1968) The Demand and Supply of Public Goods. Rand McNally \& Company.

Buck, A. H. (1894). A reference handbook of the medical sciences embracing the entire range of scientific and practical medicine and allied science (Vol. VII, p. 554). William Wood \& Company.

Candela, R. A., \& Geloso, V. (2021). Economic freedom, pandemics, and robust political economy. Southern Economic Journal, 87(4), 1250-1266.

Carson, B. (2016). Firm-led Malaria prevention in the United States, 1910-1920. American Journal of Law \& Medicine, 42(2-3), 310-332.

Carson, B. (2020). Privately preventing malaria in the United States, 1900-1925. Essays in Economic and Business History, 38, 140-192.

Chittick, G., Morrison, M., Brundage, T., \& Nichols, W. G. (2017). Short-term clinical safety profile of brincidofovir: A favorable benefit-risk proposition in the treatment of smallpox. Antiviral Research., $143,269-277$. 
Condran, G. A., \& Crimmins-Gardner, E. (1978). Public health measures and mortality in US cities in the late nineteenth century. Human Ecology, 6(1), 27-54.

Condran, G. A., \& Crimmins, E. (1979). A description and evaluation of mortality data in the federal census: 1850-1900. Historical Methods, 12(1), 1-23.

Coyne, C. J., \& Hall, A. J. (2018). Tyranny comes home: The domestic fate of US militarism. Stanford University Press.

Coyne, C. J., Yatsyshina, Y. Pandemic police states. Peace Economics, Peace Science, and Public Policy. Doi: https://doi.org/10.1515/peps-2020-0021. (forthcoming).

Crepelle, A., \& Murtazashvili, I. (2020). COVID-19, Indian reservations, and self-determination. Mercatus Center COVID-19 Response Policy Brief. https://doi.org/10.2139/ssrn.3664169.

Demsetz, H. (1969). Information and efficiency: Another viewpoint. Journal of Law and Economics, 12(1), 1-22.

Desierto, D., \& Koyama, M. (2020). Health vs. economy: Politically optimal pandemic policy. Journal of Political Institutions and Political Economy, 1(4), 645-669.

Dincecco, M., \& Onorato, M. (2017). From warfare to wealth: The military origins of urban prosperity in Europe. Cambridge University Press.

Easterlin, R. A. (1999). How beneficent is the market? A look at the modern history of mortality. European Review of Economic History, 3(3), 257-294.

Egger, G., Swinburn, B., \& Islam, F. A. (2012). Economic growth and obesity: An interesting relationship with world-wide implications. Economics \& Human Biology, 10(2), 147-153.

Ejaz, H., Alsrhani, A., Zafar, A., Javed, H., Junaid, K., Abdalla, A. E., Abosalif, K. O. A., Ahmed, Z., \& Younas, S. (2020). COVID-19 and comorbidities: Deleterious impact on infected patients. Journal of Infection and Public Health, 13(12), 1833-1839.

Fenner, F., Henderson, D. A., Arita, I., Jezek, Z., \& Ladnyi, I. D. (1988). Smallpox and its eradication. World Health Organization.

Geloso, V., \& Bologna Pavlik, J. (2021). Economic freedom and the economic consequences of the 1918 pandemic. Contemporary Economic Policy, 39(2), 255-263.

Geloso, V., Murtazashvili, I. Can governments deal with pandemics? Cosmos + Taxis. (forthcoming).

Geloso, V., \& Salter, A. (2020). State capacity and economic development: Causal mechanism or correlative filter? Journal of Economic Behavior and Organization, 170, 372-385.

Goodman, N. P., Coyne, C. J., Devereaux, A. Infectious disease and government growth. The Independent Review. (forthcoming).

Goodman-Bacon, A., \& Marcus, J. (2020). Using difference-in-differences to identify causal effects of COVID-19 policies. SSRN: https://ssrn.com/abstract=3603970.

Gorodnichenko, R., \& Roland, G. (2017). Culture, institutions, and the wealth of nations. Review of Economics and Statistics, 99(3), 402-416.

Hall, J. C., \& Lawson, R. A. (2014). Economic freedom of the world: An accounting of the literature. Contemporary Economic Policy, 32(1), 1-19.

Heckelman, J. C., \& Stroup, M. D. (2000). Whcich economic freedoms contribute to growth? Kyklos, 53(4), 527-544.

Higgs, R. (1979). Cycles and trends of mortality in 18 large American cities, 1871-1900. Explorations in Economic History, 16(4), 381-408.

Higgs, R. (1987). Crisis and leviathan critical episodes in the growth of American government. Oxford University Press.

Higgs, R., \& Booth, D. (1979). Mortality differentials within large American cities in 1890. Human Ecology, 7(4), 353-370.

Kitchens, C. (2013). A dam problem: TVA's fight against malaria, 1926-1951. The Journal of Economic History, 73(3), 694-724.

Lawson, R. A., Murphy, R. H., \& Williamson, C. R. (2016). The relationship between income, economic freedom, and BMI. Public Health, 134, 18-25.

Leeson, P. T., \& Thompson, H. A. (2021). Public choice and public health. Public Choice. https://doi.org/ 10.1007/s11127-021-00900-2.

McGuire, R. A., \& Coelho, P. R. (2011). Parasites, pathogens, and progress: Diseases and economic development. MIT Press.

Meeker, E. (1972). The improving health of the United States, 1850-1915. Explorations in Economic History, 9, 353-373.

McCannon, B. C., \& Hall, J. C. (2021). Stay-at-home orders were issued earlier in economically unfree states. South Economics Journal, 87(4), 1138-1151. 
McKinley, J. M., Mueller, U., Atkinson, P. M., Ofterdinger, U., Cox, S. F., Doherty, R., ... \& PawlowskyGlahn, V. (2020). Chronic kidney disease of unknown origin is associated with environmental urbanisation in Belfast, UK. Environmental Geochemistry and Health. https://doi.org/10.1007/ s10653-020-00618-y.

Murphy, R. H., \& Lawson, R. A. (2018). Extending the economic freedom of the World index to the cold war era. The Cato Journal, 38(1), 265.

Murphy, R. \& Stansel, D. (2019). Economic Freedom in U.S. States in the $19^{\text {th }}$ century. Working Paper.

Murray, D. R., Schaller, M., \& Suedfeld, P. (2013). Pathogens and politics: Further evidence that parasite prevalence predicts authoritarianism. PLOS ONE, 8(5), e62275.

O'Reilly, C., \& Powell, B. (2015). War and the growth of government. European Journal of Political Economy, 40, 31-41.

Ott, J. (2018). Measuring economic freedom: Better without size of government. Social Indicators Research, 135(2), 479-498.

Piano, E. E. (2019). State capacity and public choice: A critical survey. Public Choice, 178(1), 89-109.

Pelletier, F., Légaré, J., \& Bourbeau, R. (1997). Mortality in Quebec during the nineteenth century: From the state to the cities. Population Studies, 51(1), 93-103.

Prados De La Escosura, L. (2016). Economic freedom in the long run: Evidence from OECD countries (1850-2007). The Economic History Review, 69(2), 435-468.

Rånge, M., \& Sandberg, M. (2017). Political Institutions and regimes since 1600: A new historical data set. Journal of Interdisciplinary History, 47(4), 495-520.

Rosengren, A., Smyth, A., Rangarajan, S., Ramasundarahettige, C., Bangdiwala, S. I., AlHabib, K. F., Avezum, A., Boström, K. B., Chifamba, J., Gulec, S., Gupta, R., Igumbor, E. U., Iqbal, R., Ismail, N., Joseph, P., Kaur, M., Khatib, R., Kruger, I. M., Lamelas, P., ... Lear, S. A. (2019). Socioeconomic status and risk of cardiovascular disease in 20 low-income, middle-income, and high-income countries: The Prospective Urban Rural Epidemiologic (PURE) study. The Lancet Global Health, 7(6), e748-e760.

Roth, G. A., Abate, D., Abate, K. H., Abay, S. M., Abbafati, C., Abbasi, N., Abbastabar, H., Abd-Allah, F., Abdela, J., Abdelalim, A., Abdollahpour, I., Abdulkader, R. S., Abebe, H. T., Abebe, M., Abebe, Z., Abejie, A. N., Abera, S. F., Abil, O. Z., Abraha, H. N., Abrham, A. R., et al. (2018). Global, regional, and national age-sex-specific mortality for 282 causes of death in 195 countries and territories, 1980-2017: A systematic analysis for the global burden of disease study 2017. The Lancet, 392(10159), 1736-1788.

Troesken, W. (1999). Typhoid rates and the public acquisition of private waterwork, 1880-1920. Journal of Economic History, 59(4), 927-948.

Troesken, W. (2015). The pox of liberty: How the constitution left Americans rich, free, and prone to infection. University of Chicago Press.

Weingast, B. R. (1995). The economic role of political institutions: market-preserving federalism and economic development. Journal of Law, Economics, and Organization, 11(1), 1-31.

Yasuba, Y. (1962). Birth rates of the white population in the United State: An economic study. Johns Hopkins Press.

Publisher's Note Springer Nature remains neutral with regard to jurisdictional claims in published maps and institutional affiliations. 